\title{
Hepatic progenitor cells in canine and feline medicine: potential for regenerative strategies
}

\author{
Hedwig S Kruitwagen*, Bart Spee and Baukje A Schotanus
}

\begin{abstract}
New curative therapies for severe liver disease are urgently needed in both the human and veterinary clinic. It is important to find new treatment modalities which aim to compensate for the loss of parenchymal tissue and to repopulate the liver with healthy hepatocytes. A prime focus in regenerative medicine of the liver is the use of adult liver stem cells, or hepatic progenitor cells (HPCs), for functional recovery of liver disease. This review describes recent developments in HPC research in dog and cat and compares these findings to experimental rodent studies and human pathology. Specifically, the role of HPCs in liver regeneration, key components of the HPC niche, and HPC activation in specific types of canine and feline liver disease will be reviewed. Finally, the potential applications of HPCs in regenerative medicine of the liver are discussed and a potential role is suggested for dogs as first target species for HPC-based trials.
\end{abstract}

Keywords: Liver, Progenitor cell, Dog, Cat, Regenerative medicine

\section{Introduction}

Regenerative medicine is a rapidly developing field in which diseased tissues are restored or regenerated. This interdisciplinary field converges biomedical research, technology and clinical care, and is based on the concept of employing intrinsic repair mechanisms within the tissue itself. A hallmark of regenerative medicine is the clinical use of stem cells, either by manipulation of endogenous progenitor populations in situ, or by transplantation of stem cells (autologous or allogeneic). Recent developments in human stem cell therapy are highly visible and it appears that this phenomenon is now also entering the veterinary clinic. In April 2013, Nature published a report in its news section on the growing use of stem cells in veterinary medicine. Although popularity has increased, the efficacy of many stem cell therapies is often unproven. New FDA regulations in the USA are pending and if stem cells are defined as a drug, application as a new treatment modality requires evidence-based veterinary medicine [1].

Regenerative strategies in the liver seem redundant, as adult hepatocytes are widely known for their large regenerative capacity. However, developments in the field of hepatology make clear that in severe or chronic ongoing

\footnotetext{
* Correspondence: H.S.Kruitwagen@uu.nl

Department of Clinical Sciences of Companion Animals, Faculty of Veterinary Medicine, Utrecht University, Yalelaan 104, 3584 CM, Utrecht, The Netherlands
}

liver disease, regeneration by hepatocyte replication is failing or absent [2]. In these specific circumstances liverspecific stem cells, or hepatic progenitor cells (HPCs), become activated and attempt to repopulate the liver. HPCs are a reserve compartment of adult stem/progenitor cells that reside within the liver and are found in rodents, humans, dogs and cats [3-7]. HPC activation in a diseased liver section is described as 'ductular reaction' or 'bile duct proliferation' in a histology report [8,9]. Diagnostically, it indicates severe liver disease. In addition, the presence of progenitor cell markers in hepatocellular carcinoma (HCC) is an indicator of malignancy in humans as well as dogs [10-12]. Conversely, HPCs hold potential as a therapeutic target since they are committed liver stem cells, show self-renewal capacity and can differentiate into hepatocytes and cholangiocytes (Figure 1) [13]. Literature on HPCs focuses on mouse, rat, and human. There are few publications on canine HPCs and even fewer on cat or other species and it is clear that the HPC response is often referred to as 'bile duct proliferation' when observed in liver histological sections $[8,14]$. In this terminology there is no suggestion of the presence and activation of stem cells, implying that the presence of HPCs in the liver of dogs and cats is not widely recognized and that there is no consensus on terminology in veterinary pathology. An attempt to achieve this consensus in clinical and 


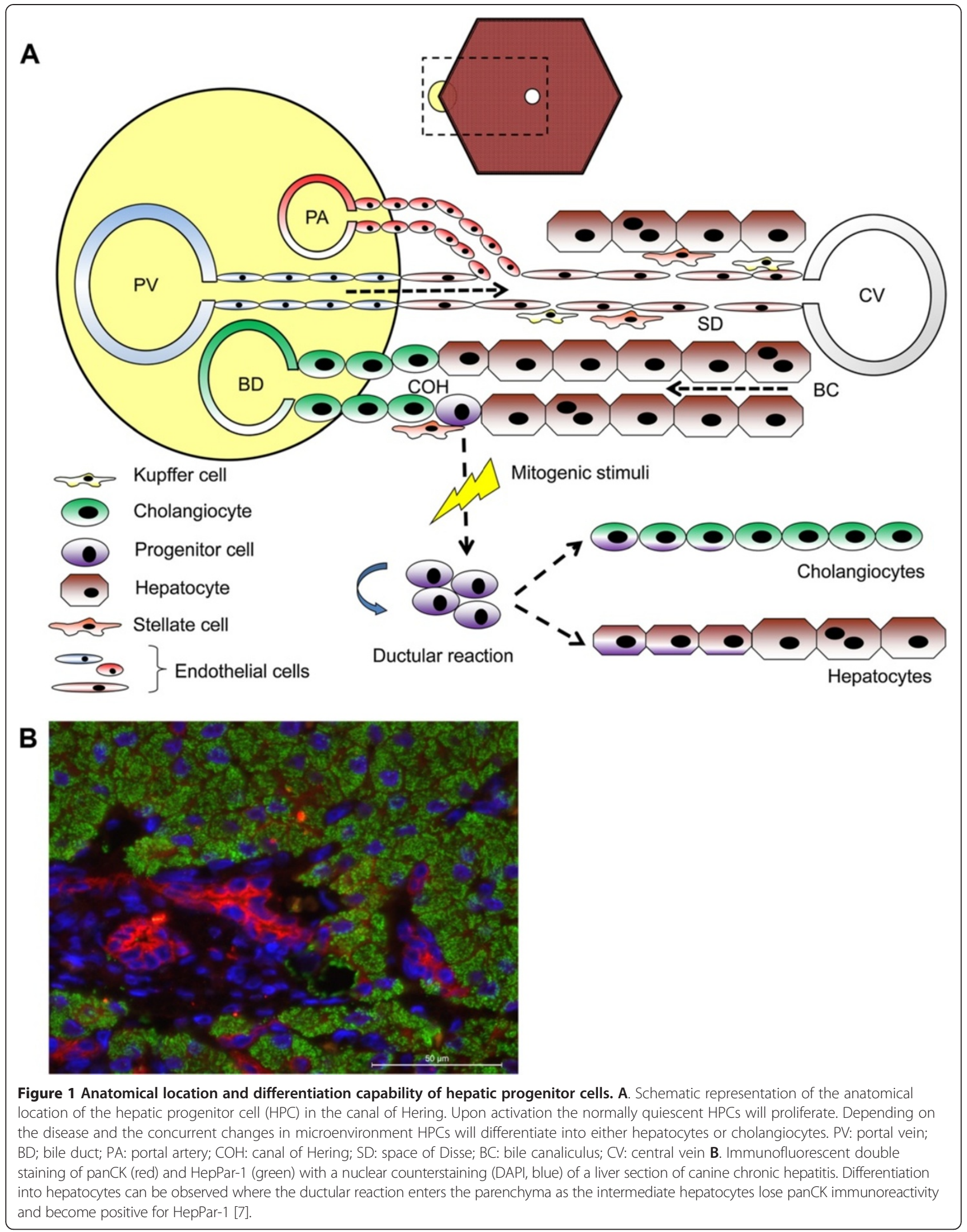


histological diagnosis of liver disease has been made by the WSAVA Liver Standardization Group.

In this review, we will provide an overview of the role of HPCs in liver regeneration and will address the most important cellular and stromal players in HPC biology. Although current knowledge about HPCs stems primarily from experimental rodent and clinical human studies, we will review available literature on HPCs in canine and feline liver regeneration, and support these with recent data from our own research. To conclude, we will discuss the possible use of HPCs for clinical purposes in veterinary regenerative medicine and for future research needs.

\section{The role of HPCs in liver regeneration}

Seventy percent of the liver consists of mature hepatocytes located in the parenchyma. These adult hepatocytes are normally quiescent, but enter the cell cycle when the liver is damaged. They can restore liver function by compensatory hyperplasia, an efficient and well-orchestrated physiological response [15]. The large replicative potential has designated hepatocytes as a stem cell of the liver in the past [16], but their lack of differentiation potential does not render them true stem cells [17]. This process of liver regeneration has been thoroughly investigated by using the partial hepatectomy ( $\mathrm{PHx})$ model in rodents as well as in dogs, and has revealed the involvement of a plethora of growth factors and cytokines [2,18-21]. Previous work by our group demonstrates that in canine liver disease the primary molecular pathways associated with liver regeneration (e.g. the hepatocyte growth factor (HGF) signaling pathway) are highly comparable with those in rodents and humans [22-24]. For the cat, the underlying molecular mechanisms of disease and regeneration have not been described.

Upon acute severe or chronic hepatic injury, hepatocyte replication is impaired or exhausted. This impairment in hepatocyte replication is linked to an increase in HPC activation [2]. For example, in biopsies of human patients with severe acute liver damage it was shown that more than 50 percent hepatocyte loss results in a lower proliferative activity of the remaining hepatocytes, when compared with less severe hepatic injuries. This was associated with a pronounced HPC response, and positively correlated with symptoms of liver failure [25]. Hepatocyte senescence occurs in chronic liver disease, which is characterized by increased p21 expression (cell cycle inhibitor) and shortened telomeres in the hepatocytes [26,27]. A report from Liu et al. showed that when hepatocytes from a cirrhotic donor rat were transplanted into a non-cirrhotic host liver, the cells engrafted but showed decreased metabolic function and delayed proliferation due to replicative senescence [28]. This phenomenon of hepatocyte senescence was also observed in a mouse model of fatty liver disease and a marked progenitor cell response was observed in the affected animals when compared to their wild type controls [29].

Hepatocyte senescence in chronic liver disease has not been investigated in the dog and cat. However, immunohistochemical stainings for PCNA or Ki67 in various canine liver diseases show prominent proliferation of hepatocytes after experimental $\mathrm{PHx}$ and mild acute hepatitis, with moderate proliferation in chronic hepatitis. Conversely, HPC response was pronounced in chronic hepatitis, moderate in mild acute hepatitis and non-existent after PHx (Figure 2) [6,30]. The response pattern of HPCs to various types of liver disease in the dog appears to be comparable to human pathology and rodent experimental findings, and recent studies suggest a similar comparison for feline HPC response [6,7,31], [Unpublished observations section: Valtolina et al.]. In all species, HPC response correlates with the severity of disease and is localized at the site of disease activity $[6,25,32,33]$. The current consensus is that the HPC pool is a reserve compartment in the liver that contributes to regeneration when hepatocytes do not replicate sufficiently to restore liver mass and function.

\section{The hepatic progenitor cell}

HPCs are present in healthy adult liver tissue and can be found in small numbers in the Canal of Hering, the smallest ramifications of the intrahepatic biliary tree, which connect to the intralobular canaliculi. These structures are located close to the portal area and are lined by both cholangiocytes and hepatocytes [34]. This is the most commonly described HPC niche, although there is still debate about the exact origin of the HPC. A number of studies state a possible biliary origin of HPCs [35-37]; other studies in humans describe extrahepatic peribiliary glands as the prime location for HPCs [38,39]; and a few publications even speculate on a hematopoietic origin of HPCs, which is also highly debated [40-44]. For this review we assume an HPC niche within the Canal of Hering, as described in mouse, rat, human, and dog $[3,4,7,45]$. HPCs can be histologically characterized by a combination of their specific morphology upon activation (ductular reaction, DR) and by marker expression. Many classic HPC-markers, such as keratin (K)7 and K19, have a shared expression with cholangiocytes, which underlines the significance of combining the interpretation of marker expression with histological evaluation. Other reported markers include CD133 and EpCAM, which are also expressed in other stem cells such as hematopoietic or embryonic stem cells (for a review, see [46]). HPCs are epithelial cells that can display mesenchymal characteristics, depending on their activation status (e.g. need for migration capacity). This is reflected in the expression of CD29 (integrin $\beta 1$ ) and CD44 (hyaluronic acid receptor and co-receptor for hepatocyte growth factor), proteins 


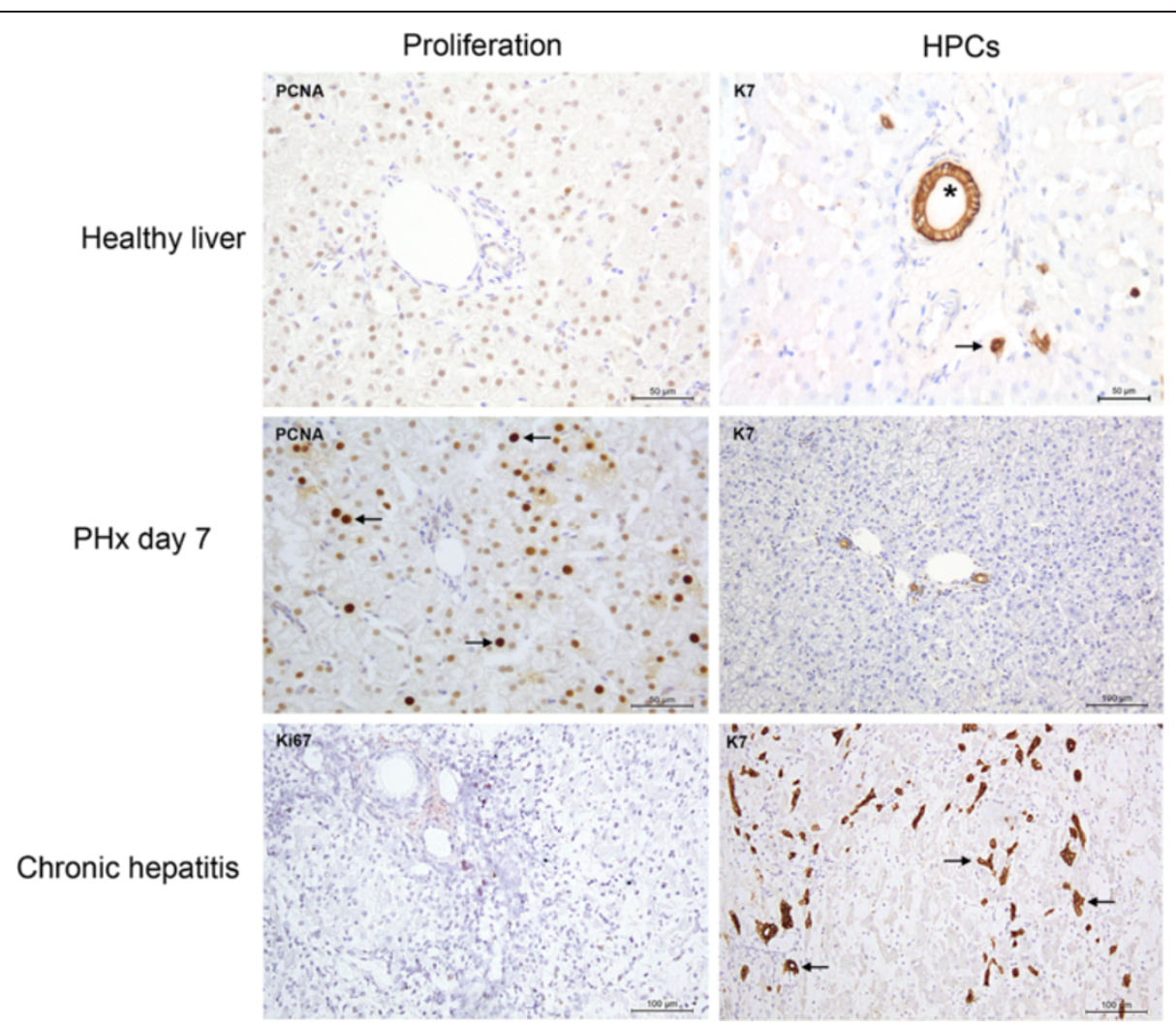

Figure 2 The first and second line of defense in canine liver regeneration. In liver sections proliferation is visualized by PCNA or Ki67 immunohistochemistry. K7 was used as a marker for hepatic progenitor cells. In healthy liver, both hepatocytes and HPCs are quiescent, indicated by a few hepatocytes that stain for PCNA and only a few K7 positive cells close to the portal area (indicated with arrow, asterisk indicates bile duct). After partial hepatectomy (PHx), liver regeneration occurs through hepatocyte proliferation (many PCNA positive hepatocytes indicated by arrows) but the HPC remains quiescent (few K7 positive cells). In chronic hepatitis the proliferative capacity of hepatocytes is exhausted indicated by a few Ki67 positive hepatocytes and a prominent ductular reaction (K7 positive, indicated by arrows) [6,30].

involved in cell-matrix interactions and potentially critical for cell migration. When reviewing HPC marker expression, interspecies differences emerge. Therefore, it is necessary to evaluate appropriate markers in the species of interest and, in rodents, to consider the model used [47]. In Table 1 we provide an overview of available literature on HPC markers in mouse, rat, human, dog, and cat. It is important to take into account that the HPC niche can be dynamic during its various states of quiescence, proliferation and differentiation, which is reflected by marker expression. Some markers (such as CD133 and Lgr5) are expressed by only a subset of cells or only upon activation $[48,49]$.

\section{Cells, signals and stroma in the HPC niche}

An essential feature of stem cell biology is the niche, or micro-environment, in which stem cells reside. It consists of neighboring cells, extracellular matrix (ECM) components and soluble and bound growth factors and cytokines that govern self-renewal and maturation/differentiation status [68]. The composition of the HPC niche is well defined and adapts during specific types of liver disease $[44,69]$. A number of cellular niche components have been described, and below we discuss the hepatic stellate cell, the macrophage and the ECM.

\section{Hepatic stellate cells}

Hepatic stellate cells (HSCs, or previously called Ito cells) are found in the space of Disse and can transform into myofibroblasts upon injury-induced activation. Quiescent HSCs are important in vitamin A storage (mainly as retinol-containing lipid droplets) and function as liver resident antigen presenting cells [70,71]. Activated HSCs produce ECM components such as collagen and are the main contributors to fibrosis development in chronic liver disease [72]. Interestingly, HSCs are also an essential mediator of the HPC response and the primary source of HGF, which stimulates hepatocyte and HPC proliferation and liver regeneration [73,74]. HSCs may also play a role in directing the differentiation of HPCs, and co-culture studies of HSCs and HPC-like cells indicate that this is probably mediated by both soluble and membrane-bound factors or matrix components [75]. 
Table 1 Comparison of HPC marker expression across species

\begin{tabular}{|c|c|c|c|c|c|}
\hline Marker & Mouse & Rat & Cat & Dog & Human \\
\hline$\overline{A 6}$ & {$[3,50]$} & & & & \\
\hline ABCG2/BCRP1 & {$[47]$} & [47] & & {$[7]$} & {$[7,48]$} \\
\hline AFP & & {$[47,51,52]$} & & [53] & {$[48,54-56]$} \\
\hline Alb & {$[57]$} & & & & {$[54,55,58]$} \\
\hline Dlk/Pref-1 & [59] & [47] & & & \\
\hline c-kit & & {$[60]$} & & & {$[48,56]$} \\
\hline CD24 & {$[50]$} & & & & \\
\hline CD29 & & [51] & & [53] & {$[54]$} \\
\hline CD34 & & {$[60]$} & & & \\
\hline CD44 & [49] & [51] & & {$[53]$} & {$[48,54,55]$} \\
\hline CD45 & & {$[60]$} & & & \\
\hline CD73 & & & & & {$[54]$} \\
\hline CD90 & & {$[52,60]$} & & & {$[54]$} \\
\hline CD133/PROM1 & {$[49,57,59,61]$} & [51] & & {$[53]$} & [48] \\
\hline CLDN3 & & & & & {$[55]$} \\
\hline chrom-A & & & & & {$[32,33]$} \\
\hline EpCAM & {$[50,57,59]$} & {$[45,51]$} & & & {$[55,62]$} \\
\hline FN14 & [59] & [51] & & {$[53]$} & \\
\hline GPC3 & & {$[52]$} & & & \\
\hline Hedgehog proteins & & & & Schotanus (unpublished data) & {$[55]$} \\
\hline HNF4a & & {$[45]$} & & [53] & \\
\hline ICAM1 & & & & & {$[55]$} \\
\hline K7 & {$[36,57]$} & {$[32,63]$} & {$[31]$} & {$[6,7,53]$} & {$[6,7,25,32,33,48,64,65]$} \\
\hline K8 & & & & & {$[33,54]$} \\
\hline K18 & & & & & {$[33,54]$} \\
\hline K19 & {$[3,37,57,59]$} & {$[32,45,51,52,63,66]$} & & {$[6,53]$} & {$[6,25,32,33,48,55,56,58,64,67]$} \\
\hline Lgr5 & [49] & & & & \\
\hline MPK & & [47] & & & \\
\hline NCAM & & & & & {$[32,48,55]$} \\
\hline NES & & & & & {$[54]$} \\
\hline Nope & {$[50]$} & & & & \\
\hline OPN & {$[37]$} & & & [53] & \\
\hline OV6 & & {$[32,45,66]$} & & & {$[32,33]$} \\
\hline Sca1 & {$[59]$} & & & & \\
\hline SOX9 & {$[36,37,49,59,61]$} & & & {$[53]$} & \\
\hline vimentin & & & & & [54] \\
\hline
\end{tabular}

References are indicated per marker per species. Expression was measured at mRNA and/or protein level and was reported for adult liver.

\section{Macrophages}

Macrophages in the liver are a second important niche component. Macrophages are activated upon hepatocyte damage and are integral to the local immune response [76]. Cytokines (e.g. TWEAK) produced by this inflammatory cell can modulate HPC behavior over large distances in the tissue $[77,78]$. HPC migration through the parenchyma was significantly decreased in mice depleted for macrophages with clodronate and subsequently subjected to liver injury [79]. Boulter et al. corroborated this finding by reporting a pivotal role of both activated myofibroblasts and macrophages in murine HPC differentiation. Mediated by Wnt and Notch signaling, respectively, macrophages are involved in the specification of hepatocyte differentiation upon hepatocellular injury and myofibroblasts promote biliary differentiation of HPCs [80]. 
These data support previous studies on the involvement of Wnt and Notch signaling in human clinical HPC activation. In human samples of acute hepatitis, a parenchymal liver disease, the activated HPC niche showed increased Wnt signaling. Active Notch signaling in the activated HPC niche was mainly observed in biliary-type diseases [48].

\section{Extracellular matrix}

A third critical component of the HPC niche is the extracellular matrix (ECM) and its specific composition. In particular, laminin has been shown in both mouse models and human fibrotic liver disease to play an important role in HPC biology. A laminin matrix develops in many liver diseases and consistently surrounds the ductular reaction. The deposition and remodeling of laminin is required for HPC proliferation and migration and it maintains the undifferentiated state of the HPCs. It is only when the HPCs 'escape' from the laminin matrix and enter the parenchyma that differentiation occurs $[44,81,82]$. HPCs express markers such as CD29 and CD44, clearly indicating that they have the molecular make-up to communicate with their ECM [59,83]. Interestingly, ECM remodeling is modified by HSCs and macrophages through expression of matrix metalloproteinases (MMPs) and tissue inhibitors of metalloproteinases (TIMPs), and is associated with the extent of ductular reaction and fibrosis [76,84]. Several studies suggest a direct relation of HPCs with increased fibrosis development and remodeling [85,86].

To date, there are only a few publications on HPC niche components in dog. An immunohistochemistry study evaluated the inflammatory infiltrate and fibrosis in samples of canine chronic hepatitis, and recorded an increased amount of 'bile duct proliferation' in cases with marked inflammation and more advanced stages of fibrosis. A positive correlation was found between the stage of fibrosis and the number of myofibroblasts and bile duct proliferation [87]. The location and characteristics of quiescent canine HSCs and portal myofibroblasts were characterized in healthy liver. HSCs were found in the space of Disse as previously described for other species [88]. A subsequent study focused on samples of canine chronic hepatitis and lobular dissecting hepatitis and reported a positive correlation between the presence of tenascin- $C$, a specific component of ECM, and stage of fibrosis, degree of inflammation and the number of $K 7$ positive cells [89]. These findings confirm HPC activation upon severe liver disease in the dog and suggest an association with stellate cells and/or myofibroblasts, but do not exactly specify the HPC niche components.

A publication on the relation between HPCs, HSCs, fibrosis and disease severity in healthy and diseased liver samples describes the presence of activated HSCs in close vicinity to the ductular reaction in all types of liver disease studied. In liver disease with fibrosis, HPC activation was most pronounced and both HPCs and HSCs localized to the primary site of injury [6]. This was substantiated by a second study, using immunofluorescent double stainings to evaluate HPCs and their niche in different types of liver disease (Figure 3). Activated stellate cells, characterized by positive alpha-smooth muscle actin $(\alpha S M A)$, were predominantly present in fibrotic liver diseases, such as lobular dissecting hepatitis and chronic hepatitis. HSCs colocalized with the prominent ductular reaction and this colocalization was also seen for laminin at the site of disease activity where it consistently surrounded the ductular reaction. Total macrophage numbers were

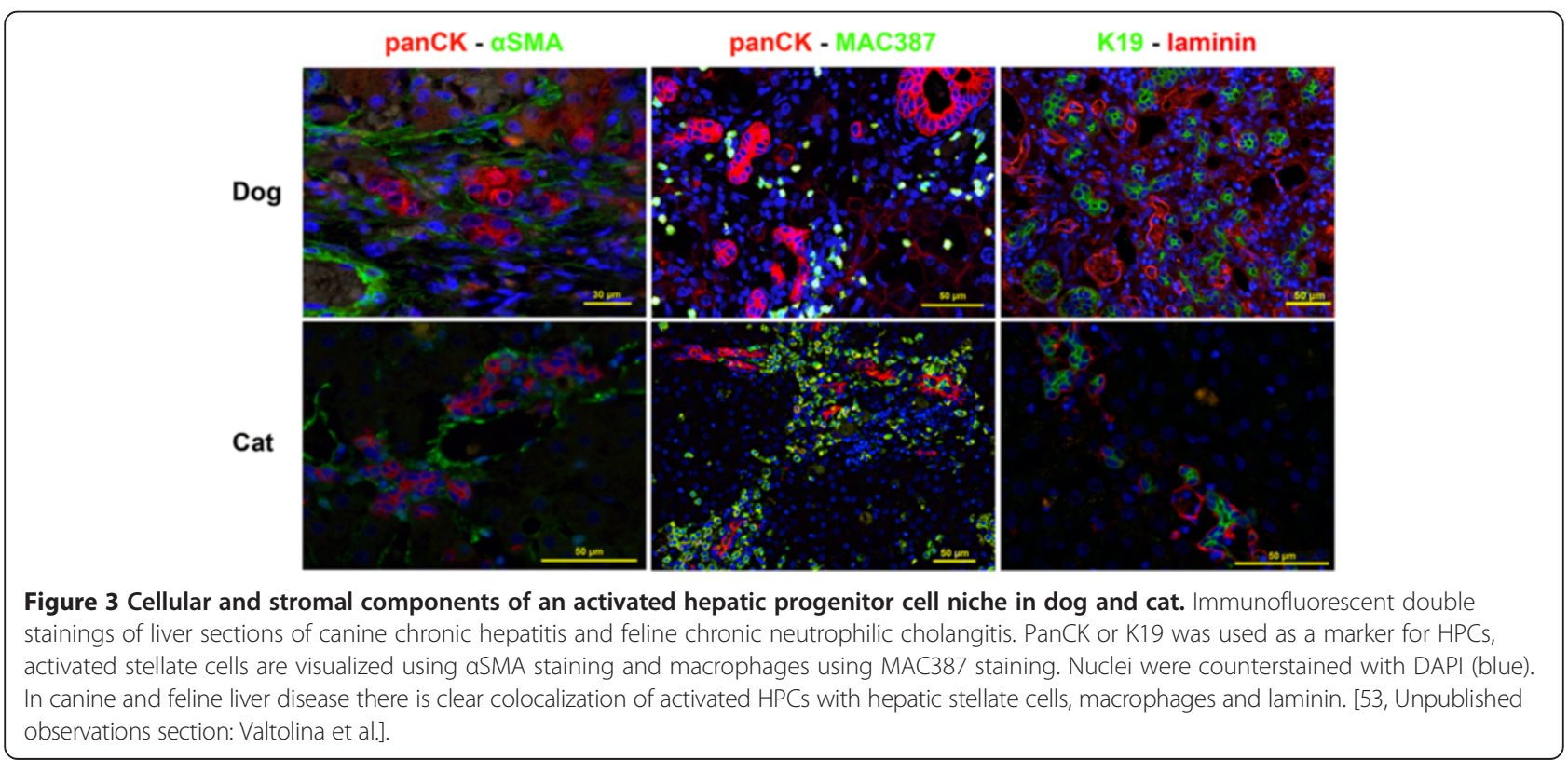


significantly increased in chronic hepatitis and lobular dissecting hepatitis. Although macrophages were identified throughout the parenchyma, they appeared to cluster at the injury site; periportal in acute hepatitis and in the fibrotic septa in chronic hepatitis [53].

To our knowledge no literature available for cats on the interaction or co-occurrence of HPCs, HSCs, macrophages and/or ECM. In light of the similar presence of HPCs in liver disease in cats, one would also expect a highly activated and comparable HPC niche in these animals [14,31]. Recent unpublished data indeed show similar involvement of HSCs, macrophages and laminin in the feline HPC niche (Figure 3) [Unpublished observations section: Valtolina et al.].

\section{HPC activation in different types of liver disease in man, dog and cat}

In the following section, the HPC response is described as it occurs in various forms of hepatitis, biliary disease and liver tumors. Figure 4 shows a representative selection of diseased canine and feline liver sections stained for K19.

\section{Acute hepatitis}

In human hepatology, severe acute parenchymal liver failure is most often caused by viral infections (e.g. hepatitis A, B, E) and ingestion of toxic substances (e.g. acetaminophen, Amanitum mushrooms) [90,91]. Massive hepatocyte loss triggers an HPC response, and is most apparent in human subjects suffering from acute submassive necrosis [25,64]. This response will rapidly develop and already after 24 hours a prominent ductular reaction can be observed. Proliferation is followed by differentiation, during which the ductular reactions give rise to 'hepatocyte-like cells' (also identified as intermediate hepatocytes) that spread into the parenchyma [32].

In the dog and cat, acute liver injury most often presents as (mild) acute hepatitis and is characterized by

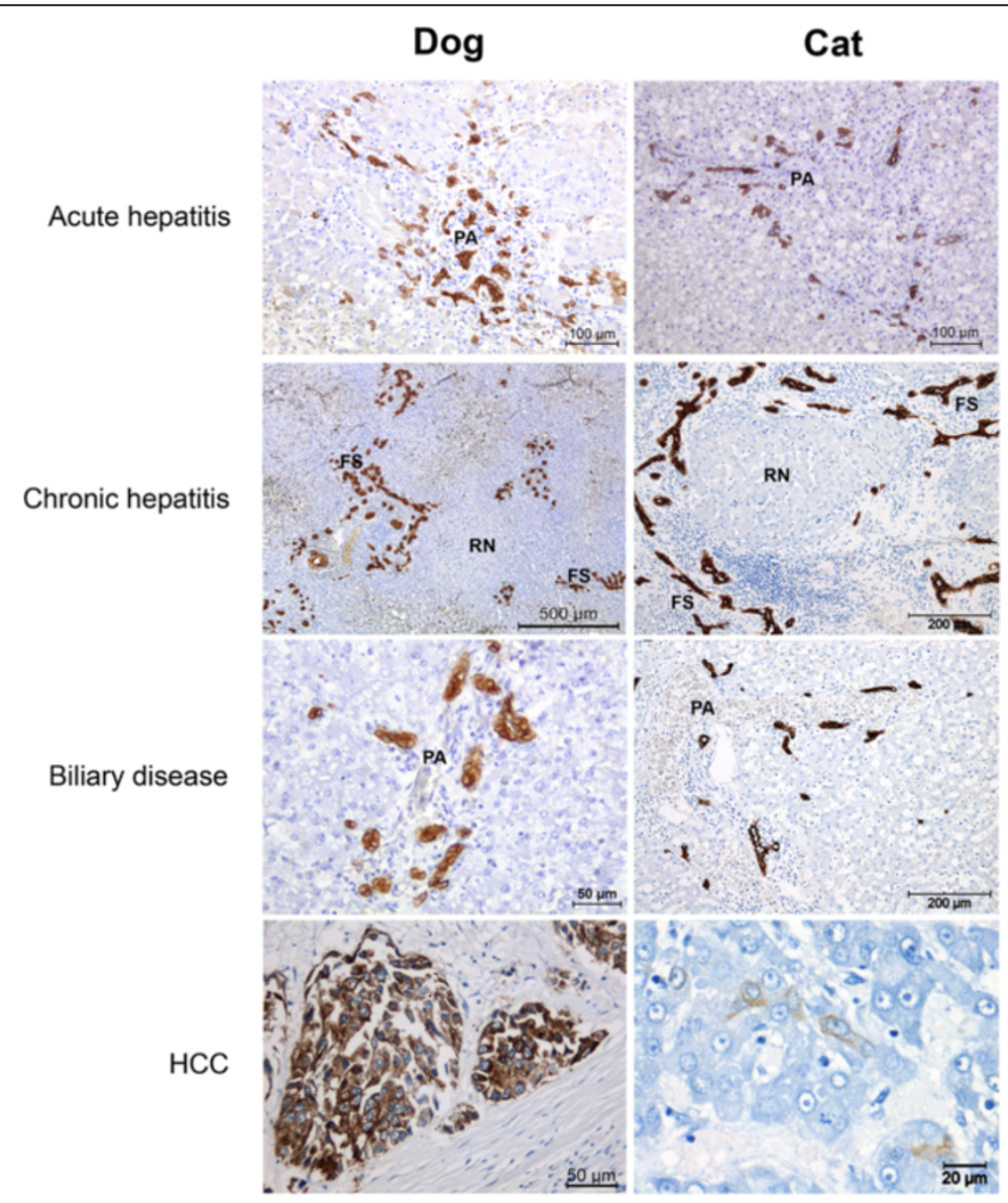

Figure 4 Hepatic progenitor cell activation in liver disease in dog and cat. K19 immunohistochemistry of liver sections from different types of liver disease in dog and cat. HPCs are activated in acute and chronic hepatitis and in biliary disease. The extent and location of the ductular reaction depends on type and severity of disease. Canine extrahepatic cholestasis and feline neutrophilic cholangitis were selected as representative biliary diseases. The lower panel shows K19 positive hepatocellular carcinoma in dog and cat. [6,11, Unpublished observations section: Valtolina et al., Van Sprundel et al.]. 
inflammation and apoptosis/necrosis. Fulminant hepatitis is rarely diagnosed in the veterinary clinic. Etiology is not always known but numerous causative agents have been described. Similar to human hepatology, viral infections can cause acute hepatitis (e.g. canine adenovirus I, canine or feline herpesvirus) and ingestion of toxic substances (iatrogenic or accidental) can result in considerable hepatocellular damage (e.g. Amanitum mushrooms, Cyanophyceae algae, acetaminophen, and benzodiazepines) [9]. The involvement of the HPC compartment in canine and feline acute hepatitis has been described in only very few studies. For canines, a ductular reaction has been observed localized to the site of injury (primarily periportal in acute hepatitis), accompanied by intermediate cells (recognized among others by submembranous $\mathrm{K} 7$ staining), suggesting early differentiation [7]. In addition, colocalization of activated HPCs and HSCs has been observed [6]. Ijzer et al. published the only paper specifically describing HPC behavior in liver disease of six cats with acute or fulminant hepatitis. In the periportal areas, there was evidence of an extensive ductular reaction, branching into the parenchyma, containing mitotic figures [31].

\section{Chronic hepatitis}

In humans, chronic hepatitis results in morbidity and mortality world-wide. Important causes are viral infections (e.g. hepatitis C), alcohol abuse, and autoimmune disease [92]. In human chronic hepatitis, the HPC compartment is activated when hepatocyte replication becomes exhausted. A ductular reaction develops and expands with disease severity $[33,65,67]$.

In veterinary medicine, chronic hepatitis is seen predominantly in dogs and infrequently in cats $[93,94]$. Fibrosis is the histological hallmark and is accompanied by inflammation and hepatocyte apoptosis/necrosis. Regeneration will occur to some extent; in cirrhosis this is represented by hyperplastic nodules of newly formed hepatocytes which emerge between the fibrotic septa [9]. HPCs and their niche are activated and a clear ductular reaction develops at the site of disease activity, which is usually in and adjacent to the fibrotic septa. HSCs are also strongly activated, differentiate into myofibroblasts, and are found at the site of fibrosis surrounding the activated HPCs [6,7]. Chronic hepatitis in dogs is perhaps best characterized as a degenerative process with unsuccessful regenerative attempts in most cases.

\section{Fatty liver disease}

Human non-alcoholic steatohepatitis (NASH) and fatty liver disease ((NA)FLD) are increasingly common hepatic disorders associated with obesity and insulin-resistance [95]. Storage of large quantities of fat and subsequent inflammation can ultimately result in liver fibrosis, cirrhosis and HCC. Human FLD is associated with increased oxidative stress and inhibition of hepatocyte replication. A strong HPC response is observed, which correlates with disease severity and fibrosis [96]. A recent study by Nobili et al. showed similar results in pediatric NASH and NAFLD and revealed adipokine signaling in activated HPCs, suggesting an active (or reactive) role in the steatosis process [97].

In cats, one of the most common hepatic parenchymal diseases is hepatic lipidosis, a fat storage disease. Hepatocytes accumulate fat vacuoles, microscopically appreciated as micro- or macrovesicular steatosis [98,99]. In sections of feline hepatic lipidosis a ductular reaction was observed, which extended into the periportal parenchyma and was associated with intermediate hepatocytes [31]. Awareness about the existence of feline HPCs during hepatic lipidosis and the appropriate terminology describing their histological appearance are currently lacking [98]. Since they possibly share a common etiology of metabolic dysfunction, the histological similarity of feline lipidosis to human NASH and NAFLD at the tissue level is currently under investigation. It appears that these fat-storing hepatic diseases have a comparable histopathological reaction pattern to inflammation and fibrosis [Unpublished observations section: Valtolina et al.].

\section{Canine lobular dissecting hepatitis}

Lobular dissecting hepatitis (LDH) is unique only to dogs, and displays extraordinary clinical behavior and histology. LDH has an acute disease progression but is histologically characterized as a chronic hepatitis, due to the occurrence of extensive fibrosis. Interestingly, in LDH a massive and unrivalled expansion of the HPC pool is seen dispersed throughout the parenchyma $[6,9,89]$. When the HPC niche was studied in detail using laser-microdissection, expression of self-renewal and progenitor markers was present, but markers of hepatocyte differentiation were absent. This is indicative of a strong proliferative response that is not followed by appropriate differentiation. Recent work showed that pre-existent liver fibrosis impaired liver regeneration upon partial hepatectomy in mice. Impaired liver regeneration was associated with increased HPC proliferation and de novo fibrogenesis. Interestingly, suppression of the $\mathrm{HPC}$ response attenuated fibrogenesis and restored regeneration by mature hepatocytes [100]. Perhaps in LDH the high amount of fibrosis somehow interferes with the maturation/differentiation of the cells in the ductular reaction, suggesting a disturbed niche biology [53]. Further research is needed to clarify the potential contribution of HPCs to fibrosis progression and their potential negative contribution to liver regeneration. $\mathrm{LDH}$ could be a very interesting disease to investigate this phenomenon $[85,86]$. 


\section{Biliary disease}

In human biliary disease, a local regenerative response results in bile duct proliferation, most probably comprising of both HPC activation and proliferation of preexisting bile duct cells [32]. As markers for HPCs often overlap with cholangiocyte markers, it can be challenging to ascertain the specific origin of newly formed bile ducts. However, in the case of biliary cirrhosis specific stainings suggested HPCs to be the cell of origin to repopulate and regenerate injured bile ducts [101]. Canine biliary diseases include extrahepatic cholestasis and destructive cholangitis. These diseases present with an activated HPC niche but are not often diagnosed [53,102]. In felines, biliary disease is frequently seen, most commonly lymphocytic and neutrophilic cholangitis, and are associated with inflammatory cell infiltrates [94,103,104]. Lymphocytic cholangitis is a chronic disease that results in portal fibrosis and bile duct proliferation [14,102]. In a large cohort of feline liver biopsies Gagne et al. observed bile duct proliferation in 26 out of 27 cats with lymphocytic cholangitis. Both the extent of bile duct proliferation and the degree of fibrosis were positively correlated with the severity of the inflammatory infiltrate. In 10 out of 11 cats with neutrophilic cholangitis, an acute biliary disease, bile duct proliferation was observed [94]. Similar to humans and dogs it is likely that bile duct proliferation in cats involves both cholangiocytes and HPCs.

\section{Liver tumors}

An emerging research area focuses on the association between HPCs and liver tumors, both in man and dog. This association is plausible, as HPCs have self-renewal capacity and migratory potential, which is required for invasion and metastasis [105]. However, the presence of HPC features within a liver tumor can be explained by more than one theory. First, HPCs are described as a possible cell of origin for hepatocellular carcinoma (HCC) and cholangiolocellular carcinoma (CLC, a specific type of cholangiocarcinoma), although no one has yet directly shown this lineage relationship [10,106-109]. Second, the presence of HPC markers in HCC is compatible with the possible dedifferentiation of resident hepatocytes that undergo malignant transformation, resulting in the expression of immature markers like K19 on HCCs $[106,110]$.

There is clinical evidence that expression of HPC markers in human $\mathrm{HCC}$ is a negative prognostic indicator, as these tumors show a higher recurrence rate and shortened patient survival $[10,111]$. In dogs, the presence of progenitor (K19) and malignancy (glypican-3) markers was evaluated immunohistochemically, and related to a histological grade and a staging score (including local or distant metastasis). The occurrence of K19 positive HCCs was $12 \%$, which resembles the prevalence in humans. This
K19 positive subset was poorly differentiated and more likely to metastasize, suggesting that K19 may be a malignancy marker in canine HCC [11]. However, for both dog and human it is still unclear whether HPCs are the cell of origin in these types of liver cancer. For liver tumors in cats, an association with HPC characteristics is under investigation by our group [Unpublished observations section: Van Sprundel et al.]. Patnaik et al. demonstrated in a retrospective study of 47 feline liver tumors that the majority of neoplasms were epithelial and primarily of biliary origin [112]. Further research is required to understand whether HPC markers are a prognostic indicator in feline liver tumors.

Ultimately, while further studies are required to reach a definitive answer on the cellular origin of liver tumors, the association between HPC markers and malignancy is now widely acknowledged.

\section{HPCs in regenerative medicine}

For severe parenchymal or biliary liver diseases, definitive and curative treatment options are currently lacking in both human and veterinary medicine. In humans, the final treatment option is a liver transplantation, but many patients die while on the waiting list (for actual data on US organ transplants see UNOS website [113]). Moreover, not all grafts remain viable after transplantation (e.g. due to rejection), warranting extensive immunosuppression or a second transplantation if possible. In dog and cat, liver transplantation is not performed. Since the etiology of liver disease is often not known, current therapy in veterinary medicine is restricted to symptomatic treatment and the use of corticoids [114-117]. To be able to improve patient survival and disease outcome, new curative therapies for advanced liver disease are required. Hepatocyte transplantations have been studied most extensively and have been performed in human patients with metabolic liver disease [118-120]. The use of hepatocytes does, however, not solve the problem of donor-shortage. Additionally, hepatocytes cannot be expanded to reach sufficient numbers for transplantation [121] which also inhibits the establishment of cell banks. The development of 'humanized livers', where murine or porcine host livers are used as an in vivo bioreactor to grow (human) hepatocytes, are potential ways to bypass this problem [122-124], but further research is needed to explore its potential for therapeutic use. Especially for veterinary medicine this approach could raise ethical questions. HPC-based treatment modalities could avoid the problems encountered when using hepatocytes for transplantation. HPCs can self-renew, generating a stable pool of progenitors, and can differentiate into newly generated hepatocytes or cholangiocytes which restore liver function [13,125]. There are two regenerative strategies that could be employed in 
the (veterinary) clinical use of HPCs and we will briefly discuss them in the light of previous studies (Figure 5).

The first option would be to target a patient's own HPC population in vivo by specific drugs or small molecules. This elegant approach is quick, minimally invasive, does not carry risk of rejection, and has the potential to be relatively cost-effective. The goal would be to activate a patient's own HPC pool and to boost proliferation and/or differentiation depending on the type of liver disease. A prerequisite is that the essential signals required to mount an HPC response are known, and that these signals are specific to HPCs and do not, for example, activate HSCs and cause excessive fibrosis. Additionally, one needs to consider that overstimulation of the HPC pool might have unexpected and undesirable side effects. HPCs have the capacity of regenerating the liver but in many diseases this is too little and too late. Possibly in these cases specific pathological or molecular characteristics somehow interfere with HPC proliferation or differentiation. Therefore, any signal that is found to benefit the HPC response must be reviewed in a clinical and diseasespecific perspective. This highly promising but very challenging approach is currently unexplored in all species. Once these signals are unraveled this approach may become a primary focus for the development of new hepatic regenerative treatments.
The second option is to use differentiated HPCs as a cell source for transplantation, either autologous or allogeneic. Technically it is possible to harvest autologous HPCs from a liver biopsy, expand them in culture and differentiate them into hepatocytes for transplantation purposes. In case of inherited metabolic disease, gene correction could be applied before transplantation. HPCs can be cultured in vitro upon isolation from primary canine liver tissue as shown by Arends et al. [126]. Using a plate-and-wait method, they were able to grow colonies of canine HPCs from the non-parenchymal fraction of a digested liver sample within a few weeks. Unfortunately, in cases of urgent clinical needs, this culture method as an autologous source for transplantation would not be feasible. In chronic cases, however, this would be an option and would circumvent rejection issues. Optimization of culture conditions of primary HPCs is needed in addition to characterization of cells in culture, most importantly, self-renewal and differentiation capacity and stability. A promising recent development is the discovery of Lgr5 positive cells in injured mouse livers that can be FACS sorted or isolated as 'ducts' and form organoids upon 3D culturing [49,127]. These cells rapidly expand, have the capacity to differentiate into hepatocytes, and can be kept in culture for more than a year, while maintaining their genomic integrity. An important caveat in clinical HPC

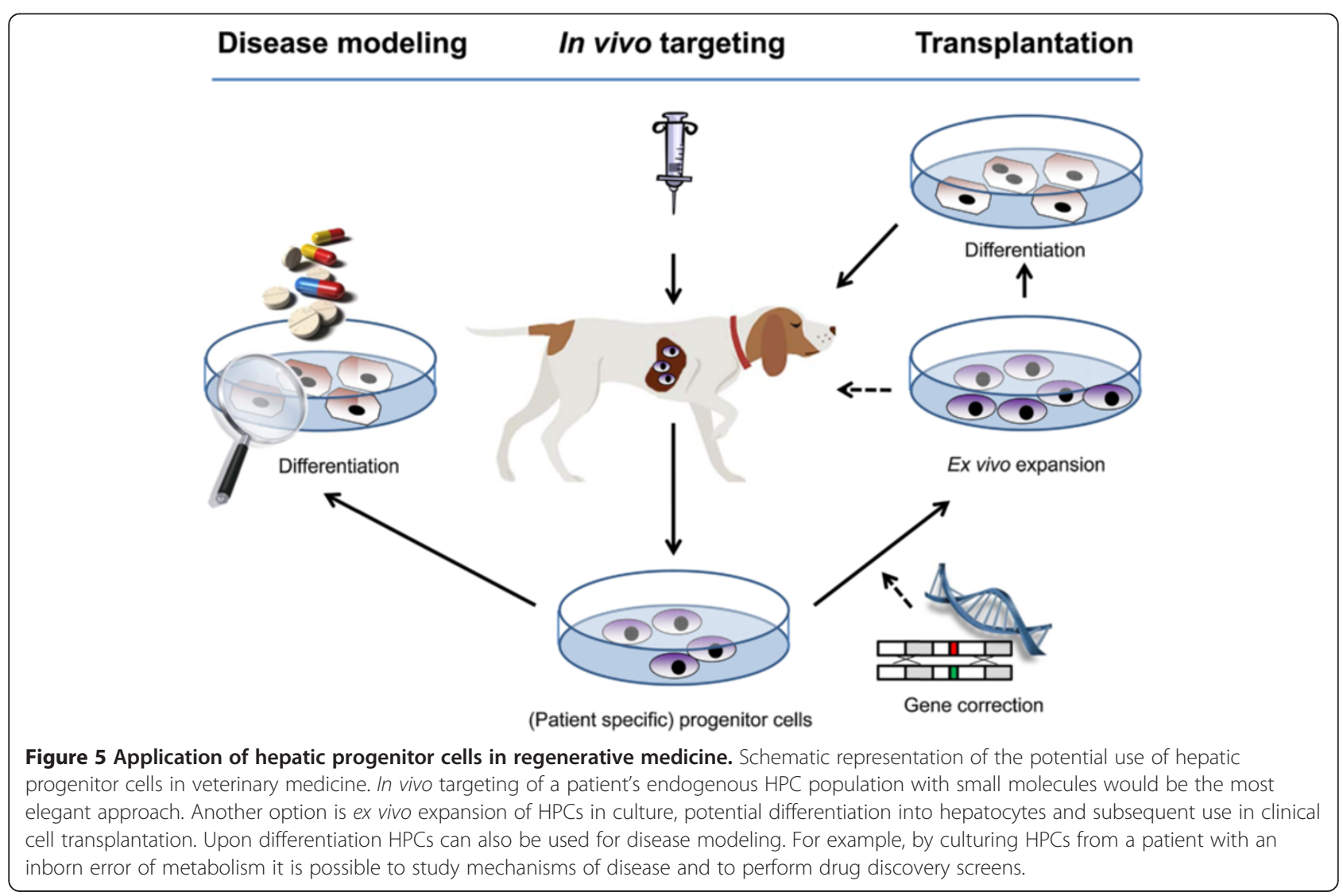


transplantation are the costs associated with the expansion of HPCs in culture. In veterinary medicine this must be balanced against the amount a pet owner is willing to pay for treatment. The costs will be highly influenced by the number of patients that could benefit from a new therapy [128]. In a UK study, the prevalence of chronic hepatitis in a dog population from first opinion practices was $12 \%$ [129], supporting an economical niche to develop new therapeutics for veterinary liver disease. The fact that treatment of dogs may serve as pre-clinical studies for human drug development could provide an economically interesting approach for pharmaceutical industries. The predicted doubling frequency of end stage liver disease in man worldwide shows the medical and economic relevance to design new therapies for human liver disease [113]. As stem cell-based therapies are being developed for multiple organs and diseases, advances are likely to be made in the near future [128].

When planning the use of HPCs for cell transplantation, three variables are essential: cell number, engraftment potential and differentiation state. The cell number administered may be critical for functional recovery of a damaged liver. An indication of the number necessary can be derived from hepatocyte transplantation studies. Jorns et al. provided a concise literature overview of hepatocyte transplantations in various species, including human, which may be most relevant for application in veterinary medicine [130]. The number of transplanted cells depends on the infusion rate and injection route, and can be divided over multiple sessions. It is accepted that for correction of a genetic metabolic disease, 2-5\% repopulation is sufficient to correct the phenotype [13]. Generally, billions of hepatocytes are used for intraportal delivery in human. Engraftment potential of hepatocytes may be very different than that of stem cells. In addition, the host environment of the diseased liver, and thus the type of disease, determines successful engraftment and therefore the number of cells needed for functional recovery. Finally, the differentiation status of the HPCs is important for the success of transplantation. The stage of maturation may determine homing and engraftment ability of HPCs. For example, undifferentiated HPCs have the capacity to migrate $[33,79]$. On the other hand, a cell in a more differentiated state with developing hepatocyte characteristics might pose an attractive clinical application in cases of acute liver failure.

With respect to HPC transplantation, metabolic diseases will probably be the first to be addressed in both dog and human. In dogs, transplantation of hepatocytes has been reported in a number of studies, mostly in Dalmatians as a model for metabolic disease (hyperuricosuria) [131-133]. In these types of diseases, improvement of the phenotype can be accomplished by providing a relatively low number of cells from a healthy donor, or upon genetic correction of autologous cells. The COMMD1 deficient dog presenting with copper storage disease resulting in chronic hepatitis, provides an excellent model for clinical HPC transplantation trials $[134,135]$. Such studies will reveal important information on efficacy and safety of HPC transplantation and will facilitate translation of this therapeutic strategy to the veterinary and human clinic. Diseases with a more complex pathophysiology, such as chronic hepatitis involving fibrosis and remodeling of tissue architecture, will be more challenging. These types of diseases will require a multimodal approach targeting not only hepatocyte regeneration but also fibrosis resolution and modulation of inflammation. Current developments in anti-fibrotic therapies and the co-transplantation of mesenchymal stem cells or macrophages to modulate inflammatory responses may aid the development of new regenerative therapies for chronic and severe liver diseases in man and dog $[136,137]$.

\section{Conclusions}

There is much promise in the use of HPCs in regenerative therapies for both human and veterinary medicine.

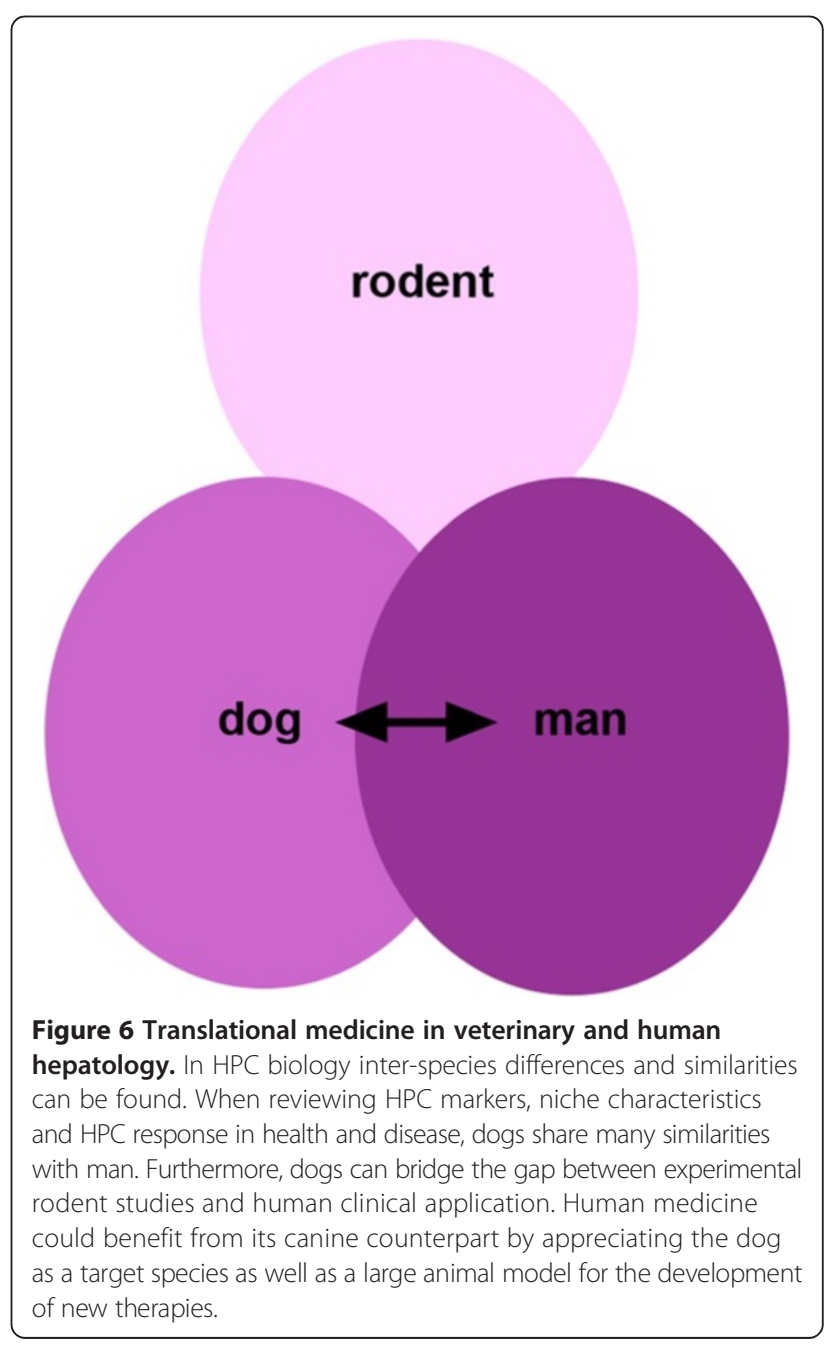


Fundamental studies in toxic and genetic rodent models, together with (comparative) histo-pathological studies in humans have determined HPCs to be clinically relevant. In canines, important molecular and cellular reaction patterns in particular liver diseases are reported, and characterize HPCs and their niche. Overall, HPC marker expression in dogs is comparable to that of humans, as is response to injury and the cell types involved in modulating HPC response. This suggests that the therapeutic potential of these cells is similar in dog when compared to man, and opens up the potential for developing new strategies for currently untreatable canine liver diseases (Figure 6).

On the other hand, there is still much to be conducted in feline hepatology. As with canine investigations, studies on cat liver disease and pathology would benefit from focusing on the molecular mechanisms of disease and regeneration in comparison to human and canine models, including the presence and characteristics of feline HPCs. In addition, feline lipidosis and cholangitis, diseases that are rare in dogs, may provide important models for human steatohepatitis and biliary disease.

We conclude that humans and dogs share many similarities with respect to liver disease and HPC biology, especially since dogs have spontaneous liver disease that equally requires treatment. With the emergence of regenerative medicine, veterinary and human medicine have the unique opportunity to advance potential therapies and technologies together. In particular, human medicine could greatly benefit from HPC-based trials in dogs.

\section{Unpublished observations}

Valtolina C, Muys J, Penning LC, Grinwis GG, Schotanus BA: Characterization of the feline hepatic progenitor cell niche in health and disease, manuscript in preparation.

Van Sprundel RGHM, Van Den Ingh TSGAM, Guscetti F, Kershaw O, Kanemoto H, Van Gils HM, Rothuizen J, Spee B: Classification of primary hepatic tumours in the cat, manuscript in preparation.

\begin{abstract}
Abbreviations
HPC: Hepatic progenitor cell; HCC: Hepatocellular carcinoma; PHx: Partial hepatectomy; HGF: Hepatocyte growth factor; PCNA: Proliferating cell nuclear antigen; DR: Ductular reaction; K (7): Keratin (7); ECM: Extracellular matrix; HSC: Hepatic stellate cell; MMP: Matrix metalloproteinase; TIMP: Tissue inhibitor of matrix metalloproteinase; aSMA: Alpha smooth muscle actin; NASH: Non-alcoholic steatohepatitis; NAFLD: Non-alcoholic fatty liver disease; LDH: Lobular dissecting hepatitis; CLC: Cholangiolocellular carcinoma.
\end{abstract}

\section{Competing interests}

The authors declare that they have no competing interests.

\section{Authors' contributions}

Authors HS Kruitwagen, B Spee and BA Schotanus contributed equally to the writing of this manuscript and preparation of the figures. All authors read and approved the final manuscript.

\section{Authors' information}

Department of Clinical Sciences of Companion Animals, Faculty of Veterinary Medicine, Utrecht University, The Netherlands.

\section{Acknowledgements}

The authors would like to thank Sarah Opitz for editing the manuscript. HS Kruitwagen and BA Schotanus receive funding from ZonMW for translational research on hepatic progenitor cells.

Received: 23 August 2013 Accepted: 31 December 2013 Published: 19 June 2014

\section{References}

1. Cyranoski D: Stem cells boom in vet clinics. Nature 2013, 496(7444):148-149.

2. Riehle KJ, Dan YY, Campbell JS, Fausto N: New concepts in liver regeneration. J Gastroenterol Hepatol 2011, 26(Suppl 1):203-212.

3. Wang X, Foster M, Al-Dhalimy M, Lagasse E, Finegold M, Grompe M: The origin and liver repopulating capacity of murine oval cells. Proc Natl Acad Sci U S A 2003, 100(Suppl 1):11881-11888.

4. Roskams TA, Libbrecht L, Desmet VJ: Progenitor cells in diseased human liver. Semin Liver Dis 2003, 23(4):385-396.

5. Arends B, Vankelecom H, Vander Borght S, Roskams T, Penning LC, Rothuizen J, Spee B: The dog liver contains a "side population" of cells with hepatic progenitor-like characteristics. Stem Cells Dev 2009, 18(2):343-350.

6. Schotanus BA, van den Ingh TS, Penning LC, Rothuizen J, Roskams TA, Spee B: Cross-species immunohistochemical investigation of the activation of the liver progenitor cell niche in different types of liver disease. Liver Int 2009, 29(8):1241-1252.

7. ljzer J, Schotanus BA, Vander Borght S, Roskams TA, Kisjes R, Penning LC, Rothuizen J, van den Ingh TS: Characterisation of the hepatic progenitor cell compartment in normal liver and in hepatitis: an immunohistochemical comparison between dog and man. Vet J 2010, 184(3):308-314.

8. Yoshioka K, Enaga S, Taniguchi K, Fukushima U, Uechi M, Mutoh K: Morphological characterization of ductular reactions in canine liver disease. J Comp Pathol 2004, 130(2-3):92-98.

9. Van Den Ingh TSGAM, Van Winkle T, Cullen JM, Charles JA, Desmet VJ, Rothuizen J: Morphological classification of parenchymal disorders of the canine and feline liver: 2. Hepatocellular death, hepatitis and cirrhosis. In WSAVA Standards for clinical and histological diagnosis of canine and feline liver disease. Edited by Rothuizen J, Bunch SE, Charles JA. Edinburgh, Great Britain: Saunders-Elsevier; 2006:85-102.

10. Durnez A, Verslype C, Nevens F, Fevery J, Aerts R, Pirenne J, Lesaffre E, Libbrecht L, Desmet V, Roskams T: The clinicopathological and prognostic relevance of cytokeratin 7 and 19 expression in hepatocellular carcinoma Histopathology. Histopathology 2006, 49(2):138-151.

11. van Sprundel RGHM, van den Ingh TS, Desmet VJ, Katoonizadeh A, Penning LC, Rothuizen J, Roskams T, Spee B: Keratin 19 marks poor differentiation and a more aggressive behaviour in canine and human hepatocellular tumours. Comp Hepatol 2010, 9(1):4.

12. Van Sprundel RGHM, van den Ingh TSGAM, Guscetti F, Kershaw $O$, Kanemoto H, Van Gils HM, Rothuizen J, Roskams T, Spee B: Classification of primary hepatic tumours in the dog. Vet J 2013, 197(3):596-606.

13. Sancho-Bru P, Najimi M, Caruso M, Pauwelyn K, Cantz T, Forbes S, Roskams T, Ott M, Gehling U, Sokal E, Verfaillie CM, Muraca M: Stem and progenitor cells for liver repopulation: can we standardise the process from bench to bedside? Gut 2009, 58(4):594-603.

14. Warren A, Center S, McDonough S, Chiotti R, Goldstein R, Meseck E, Jacobsen M, Rowland P, Simpson K: Histopathologic features, immunophenotyping, clonality, and eubacterial fluorescence in situ hybridization in cats with lymphocytic cholangitis/cholangiohepatitis. Vet Pathol 2011, 48(3):627-641.

15. Taub R: Liver regeneration: from myth to mechanism. Nat Rev Mol Cell Biol 2004, 5(10):836-847.

16. Overturf K, A-Dhalimy M, Ou CN, Finegold M, Grompe M: Serial transplantation reveals the stem-cell-like regenerative potential of adult mouse hepatocytes. Am J Pathol 1997, 15(5):1273-1280.

17. Fuchs $E$, Chen T: A matter of life and death: self-renewal in stem cells. EMBO Rep 2013, 14(1):39-48. 
18. Higgins GM, Anderson RM: Experimental pathology of the liver. I. Restoration of the liver of the white rat following partial surgical removal. Arch Pathol 1931, 12:186-202.

19. Francavilla A, Porter KA, Benichou J, Jones AF, Starzl TE: Liver regeneration in dogs: morphologic and chemical changes. J Surg Res 1978, 25(5):409-419.

20. Szawlowski AW, Saint-Aubert B, Gouttebel MC, Astre C, Joyeux H: Experimental model of extended repeated partial hepatectomy in the dog. Eur Surg Res 1987, 19(6):375-380.

21. Michalopoulos GK: Liver regeneration. J Cell Physio/ 2007, 213(2):286-300.

22. Spee B, Penning LC, van den Ingh TS, Arends B, ljzer J, van Sluijs FJ, Rothuizen J: Regenerative and fibrotic pathways in canine hepatic portosystemic shunt and portal vein hypoplasia, new models for clinical hepatocyte growth factor treatment. Comp Hepatol 2005, 4:7.

23. Spee B, Arends B, van den Ingh TS, Brinkhof B, Nederbragt $H$, ljzer J, Roskams T, Penning LC, Rothuizen J: Transforming growth factor beta-1 signalling in canine hepatic diseases: new models for human fibrotic liver pathologies. Liver Int 2006, 26(6):716-725.

24. Spee B, Arends B, van den Ingh TS, Roskams T, Rothuizen J, Penning LC: Major HGF-mediated regenerative pathways are similarly affected in human and canine cirrhosis. Comp Hepatol 2007, 6:8.

25. Katoonizadeh A, Nevens F, Verslype C, Pirenne J, Roskams T: Liver regeneration in acute severe liver impairment: A clinicopathological correlation study. Liver Int 2006, 26(10):1225-1233.

26. Aravinthan A, Scarpini C, Tachtatzis P, Verma S, Penrhyn-Lowe S, Harvey R, Davies SE, Allison M, Coleman N, Alexander G: Hepatocyte senescence predicts progression in non-alcohol-related fatty liver disease. $J$ Hepatol 2013, 58(3):549-556.

27. Lunz JG 3rd, Tsuji H, Nozaki I, Murase N, Demetris AJ: An inhibitor of cyclin-dependent kinase, stress-induced p21Waf-1/Cip-1, mediates hepatocyte mito-inhibition during the evolution of cirrhosis. Hepatology 2005, 41(6):1262-1271.

28. Liu L, Yannam GR, Nishikawa T, Yamamoto T, Basma H, Ito R, Nagaya M, Dutta-Moscato J, Stolz DB, Duan F, Kaestner KH, Vodovotz Y, Soto-Gutierrez A, Fox IJ: The microenvironment in hepatocyte regeneration and function in rats with advanced cirrhosis. Hepatology 2012, 55(5):1529-1539.

29. Yang S, Koteish A, Lin H, Huang J, Roskams T, Dawson V, Diehl AM: Oval cells compensate for damage and replicative senescence of mature hepatocytes in mice with fatty liver disease. Hepatology 2004, 39(2):403-411.

30. Arends B, Spee B, Hoffmann G, Jansen GE, Slump E, Auriemma E, ljzer J, Hemrika W, Romijn RA, van der Heijden-Liefkens KH, Sondermeijer PJ, van den Ingh TS, Penning LC, Rothuizen J: In vitro and in vivo bioactivity of recombinant canine hepatocyte growth factor. Vet J 2008, 178(1):70-77.

31. ljzer J, Kisjes JR, Penning LC, Rothuizen J, van den Ingh TS: The progenitor cell compartment in the feline liver: an (immuno) histochemical investigation. Vet Pathol 2009, 46(4):614-621.

32. Roskams T, De Vos R, Van Eyken P, Myazaki H, Van Damme B, Desmet V: Hepatic OV-6 expression in human liver disease and rat experiments: evidence for hepatic progenitor cells in man. J Hepatol 1998, 29(3):455-463.

33. Libbrecht $L$, Desmet V, Van Damme B, Roskams T: Deep intralobular extension of human hepatic 'progenitor cells' correlates with parenchymal inflammation in chronic viral hepatitis: can 'progenitor cells' migrate? J Pathol 2000, 192(3):373-378.

34. Roskams TA, Theise ND, Balabaud C, Bhagat G, Bhathal PS, Bioulac-Sage P, Brunt EM, Crawford JM, Crosby HA, Desmet V, Finegold MJ, Geller SA, Gouw AS, Hytiroglou P, Knisely AS, Kojiro M, Lefkowitch JH, Nakanuma Y, Olynyk JK, Park YN, Portmann B, Saxena R, Scheuer PJ, Strain AJ, Thung SN, Wanless $I R$, West $A B$ : Nomenclature of the finer branches of the biliary tree: canals, ductules, and ductular reactions in human livers. Hepatology 2004, 39(6):1739-1745.

35. Kuwahara R, Kofman AV, Landis CS, Swenson ES, Barendswaard E, Theise ND: The hepatic stem cell niche: identification by label-retaining cell assay. Hepatology 2008, 47(6):1994-2002.

36. Furuyama K, Kawaguchi Y, Akiyama H, Horiguchi M, Kodama S, Kuhara T, Hosokawa S, Elbahrawy A, Soeda T, Koizumi M, Masui T, Kawaguchi M, Takaori K, Doi R, Nishi E, Kakinoki R, Deng JM, Behringer RR, Nakamura T, Uemoto S: Continuous cell supply from a Sox9-expressing progenitor zone in adult liver, exocrine pancreas and intestine. Nat Genet 2011, 43(1):34-41.
37. Espanol-Suner R, Carpentier R, Van Hul N, Legry V, Achouri Y, Cordi S, Jacquemin P, Lemaigre F, Leclercq IA: Liver progenitor cells yield functional hepatocytes in response to chronic liver injury in mice. Gastroenterology 2012, 143(6):1564-1575. e7.

38. Turner R, Lozoya O, Wang Y, Cardinale V, Gaudio E, Alpini G, Mendel G, Wauthier E, Barbier C, Alvaro D, Reid LM: Human hepatic stem cell and maturational liver lineage biology. Hepatology 2011, 53(3):1035-1045.

39. Semeraro R, Carpino G, Cardinale V, Onori P, Gentile R, Cantafora A, Franchitto A, Napoli C, Anceschi M, Brunelli R, Bosco D, Torrice A, Reid L, Gaudio E, Alvaro D: Multipotent stem/progenitor cells in the human foetal biliary tree. J Hepatol 2012, 57(5):987-994.

40. Petersen BE, Bowen WC, Patrene KD, Mars WM, Sullivan AK, Murase N, Boggs SS, Greenberger JS, Goff JP: Bone marrow as a potential source of hepatic oval cells. Science 1999, 284(5417):1168-1170.

41. Oh SH, Witek RP, Bae SH, Zheng D, Jung Y, Piscaglia AC, Petersen BE: Bone marrow-derived hepatic oval cells differentiate into hepatocytes in 2-acetylaminofluorene/partial hepatectomy-induced liver regeneration. Gastroenterology 2007, 132(3):1077-1087.

42. Alison MR, Vig P, Russo F, Bigger BW, Amofah E, Themis M, Forbes S: Hepatic stem cells: from inside and outside the liver? Cell Prolif 2004, 37(1):1-21.

43. Vig P, Russo FP, Edwards RJ, Tadrous PJ, Wright NA, Thomas HC, Alison MR, Forbes SJ: The sources of parenchymal regeneration after chronic hepatocellular liver injury in mice. Hepatology 2006, 43(2):316-324.

44. Lorenzini S, Bird TG, Boulter L, Bellamy C, Samuel K, Aucott R, Clayton E, Andreone P, Bernardi M, Golding M, Alison MR, Iredale JP, Forbes SJ: Characterisation of a stereotypical cellular and extracellular adult liver progenitor cell niche in rodents and diseased human liver. Gut 2010, 59(5):645-654.

45. Chen YH, Chang MH, Chien CS, Wu SH, Yu CH, Chen HL: Contribution of mature hepatocytes to small hepatocyte-like progenitor cells in retrorsine-exposed rats with chimeric livers. Hepatology 2013, 57(3):1215-1224.

46. Calloni R, Cordero EA, Henriques JA, Bonatto D: Reviewing and updating the major molecular markers for stem cells. Stem Cells Dev 2013, 22(9):1455-1476.

47. Jelnes P, Santoni-Rugiu E, Rasmussen M, Friis SL, Nielsen JH, Tygstrup N, Bisgaard HC: Remarkable heterogeneity displayed by oval cells in rat and mouse models of stem cell-mediated liver regeneration. Hepatology 2007, 45(6):1462-1470

48. Spee B, Carpino G, Schotanus BA, Katoonizadeh A, Vander Borght S, Gaudio E, Roskams T: Characterisation of the liver progenitor cell niche in liver diseases: potential involvement of Wnt and Notch signalling. Gut 2010, 59(2):247-257.

49. Huch M, Dorrell C, Boj SF, van Es JH, Li VS, van de Wetering M, Sato T, Hamer K, Sasaki N, Finegold MJ, Haft A, Vries RG, Grompe M, Clevers H: In vitro expansion of single Lgr5+ liver stem cells induced by Wnt-driven regeneration. Nature 2013, 494(7436):247-250.

50. Schievenbusch S, Sauer E, Curth HM, Schulte S, Demir M, Toex U, Goeser T, Nierhoff D: Neighbor of Punc E 11: expression pattern of the new hepatic stem/progenitor cell marker during murine liver development. Stem Cells Dev 2012, 21(14):2656-2666.

51. Yovchev MI, Grozdanov PN, Zhou H, Racherla H, Guha C, Dabeva MD: Identification of adult hepatic progenitor cells capable of repopulating injured rat liver. Hepatology 2008, 47(2):636-647.

52. Grozdanov PN, Yovchev MI, Dabeva MD: The oncofetal protein glypican-3 is a novel marker of hepatic progenitor/oval cells. Lab Invest 2006, 86(12):1272-1284

53. Kruitwagen HS, Spee B, Viebahn CS, Venema HB, Penning LC, Grinwis GG, Favier RP, Van Den Ingh TSGAM, Rothuizen J, Schotanus BA: The canine hepatic progenitor cell niche: Molecular characterisation in health and disease. Vet J doi:10.1016/j.tvjl.2014.05.024.

54. Herrera MB, Bruno S, Buttiglieri S, Tetta C, Gatti S, Deregibus MC, Bussolati B, Camussi G: Isolation and characterization of a stem cell population from adult human liver. Stem Cells 2006, 24(12):2840-2850.

55. Zhang L, Theise N, Chua M, Reid LM: The stem cell niche of human livers: symmetry between development and regeneration. Hepatology 2008, 48(5):1598-1607.

56. Theise ND, Saxena R, Portmann BC, Thung SN, Yee H, Chiriboga L, Kumar A, Crawford JM: The canals of Hering and hepatic stem cells in humans. Hepatology 1999, 30(6):1425-1433. 
57. Okabe M, Tsukahara Y, Tanaka M, Suzuki K, Saito S, Kamiya Y, Tsujimura T, Nakamura K, Miyajima A: Potential hepatic stem cells reside in EpCAM + cells of normal and injured mouse liver. Development 2009, 136(11):1951-1960.

58. Demetris AJ, Seaberg EC, Wennerberg A, lonellie J, Michalopoulos G: Ductular reaction after submassive necrosis in humans. Special emphasis on analysis of ductular hepatocytes. Am J Pathol 1996, 149(2):439-448.

59. Qiu Q, Hernandez JC, Dean AM, Rao P, Darlington G: CD24 positive cells from normal adult mouse liver are hepatocyte progenitor cells. Stem Cells Dev 2011, 20(12):2177-2188.

60. Sahin MB, Schwartz RE, Buckley SM, Heremans Y, Chase L, Hu WS, Verfaillie $C M$ : Isolation and characterization of a novel population of progenitor cells from unmanipulated rat liver. Liver Transpl 2008, 14(3):333-345.

61. Dorrell C, Erker L, Lanxon-Cookson KM, Abraham SL, Victoroff T, Ro S, Canaday PS, Streeter PR, Grompe M: Surface markers for the murine oval cell response. Hepatology 2008, 48(4):1282-1291.

62. de Boer CJ, van Krieken JH, Janssen-van Rhijn CM, Litvinov SV: Expression of Ep-CAM in normal, regenerating, metaplastic, and neoplastic liver. J Pathol 1999, 188(2):201-206.

63. Paku S, Dezso K, Kopper L, Nagy P: Immunohistochemical analysis of cytokeratin 7 expression in resting and proliferating biliary structures of rat liver. Hepatology 2005, 42(4):863-870

64. Tan J, Hytiroglou P, Wieczorek R, Park YN, Thung SN, Arias B, Theise ND: Immunohistochemical evidence for hepatic progenitor cells in liver diseases. Liver 2002, 22(5):365-373.

65. Fotiadu A, Tzioufa V, Vrettou E, Koufogiannis D, Papadimitriou CS, Hytiroglou P: Progenitor cell activation in chronic viral hepatitis. Liver Int 2004, 24(3):268-274.

66. Corcelle V, Stieger B, Gjinovci A, Wollheim CB, Gauthier BR: Characterization of two distinct liver progenitor cell subpopulations of hematopoietic and hepatic origins. Exp Cell Res 2006, 312(15):2826-2836.

67. Lowes KN, Brennan BA, Yeoh GC, Olynyk JK: Oval cell numbers in human chronic liver diseases are directly related to disease severity. Am J Pathol 1999, 154(2):537-541.

68. Fuchs $\mathrm{E}$, Tumbar T, Guasch G: Socializing with the neighbors: stem cells and their niche. Cell 2004, 116(6):769-778.

69. Roskams T: Different types of liver progenitor cells and their niches. J Hepatol 2006, 45(1):1-4.

70. Geerts A: History, heterogeneity, developmental biology, and functions of quiescent hepatic stellate cells. Semin Liver Dis 2001, 21(3):311-335.

71. Winau F, Hegasy G, Weiskirchen R, Weber S, Cassan C, Sieling PA, Modlin RL, Liblau RS, Gressner AM, Kaufmann SH: Ito cells are liver-resident antigen-presenting cells for activating T cell responses. Immunity 2007, 26(1):117-129.

72. Friedman SL: Mechanisms of hepatic fibrogenesis. Gastroenterology 2008, 134(6):1655-1669.

73. Pintilie DG, Shupe TD, Oh SH, Salganik SV, Darwiche H, Petersen BE: Hepatic stellate cells' involvement in progenitor-mediated liver regeneration. Lab Invest 2010, 90(8):1199-1208.

74. Ishikawa T, Factor VM, Marquardt JU, Raggi C, Seo D, Kitade M, Conner EA, Thorgeirsson SS: Hepatocyte growth factor/c-met signaling is required for stem-cell-mediated liver regeneration in mice. Hepatology 2012, 55(4):1215-1226

75. Nagai H, Terada K, Watanabe G, Ueno Y, Aiba N, Shibuya T, Kawagoe M, Kameda T, Sato M, Senoo H, Sugiyama T: Differentiation of liver epithelial (stem-like) cells into hepatocytes induced by coculture with hepatic stellate cells. Biochem Biophys Res Commun 2002, 293(5):1420-1425.

76. Gadd VL, Melino M, Roy S, Horsfall L, O'Rourke P, Williams MR, Irvine KM, Sweet MJ, Jonsson JR, Clouston AD, Powell EE: Portal, but not lobular, macrophages express matrix metalloproteinase-9: association with the ductular reaction and fibrosis in chronic hepatitis C. Liver Int 2013, 33(4):569-579.

77. Tirnitz-Parker JE, Viebahn CS, Jakubowski A, Klopcic BR, Olynyk JK, Yeoh GC Knight B: Tumor necrosis factor-like weak inducer of apoptosis is a mitogen for liver progenitor cells. Hepatology 2010, 52(1):291-302.

78. Viebahn CS, Benseler V, Holz LE, Elsegood CL, Vo M, Bertolino P, Ganss R, Yeoh GC: Invading macrophages play a major role in the liver progenitor cell response to chronic liver injury. J Hepatol 2010, 53(3):500-507.

79. Van Hul N, Lanthier N, Espaol Suer R, Abarca Quinones J, Van Rooijen N, Leclercq I: Kupffer cells influence parenchymal invasion and phenotypic orientation, but not the proliferation, of liver progenitor cells in a murine model of liver injury. Am J Pathol 2011, 179(4):1839-1850.

80. Boulter L, Govaere O, Bird TG, Radulescu S, Ramachandran P, Pellicoro A, Ridgway RA, Seo SS, Spee B, Van Rooijen N, Sansom OJ, Iredale JP, Lowell S, Roskams T, Forbes SJ: Macrophage-derived Wnt opposes Notch signaling to specify hepatic progenitor cell fate in chronic liver disease. Nat Med 2012, 18(4):572-579.

81. Kallis YN, Robson AJ, Fallowfield JA, Thomas HC, Alison MR, Wright NA Goldin RD, Iredale JP, Forbes SJ: Remodelling of extracellular matrix is a requirement for the hepatic progenitor cell response. Gut 2011, 60(4):525-533

82. Van Hul NK, Abarca-Quinones J, Sempoux C, Horsmans Y, Leclercq IA: Relation between liver progenitor cell expansion and extracellular matrix deposition in a CDE-induced murine model of chronic liver injury. Hepatology 2009, 49(5):1625-1635.

83. Ichinohe N, Tanimizu N, Ooe H, Nakamura Y, Mizuguchi T, Kon J, Hirata K, Mitaka T: Differentiation capacity of hepatic stem/progenitor cells isolated from D-galactosamine-treated rat livers. Hepatology 2013 57(3):1192-1202.

84. Bedossa $\mathrm{P}$, Paradis $\mathrm{V}$ : Liver extracellular matrix in health and disease. J Pathol 2003, 200(4):504-515

85. Clouston AD, Powell EE, Walsh MJ, Richardson MM, Demetris AJ, Jonsson JR: Fibrosis correlates with a ductular reaction in hepatitis C: roles of impaired replication, progenitor cells and steatosis. Hepatology 2005 41(4):809-818.

86. Knight B, Lim R, Yeoh GC, Olynyk JK: Interferon-gamma exacerbates liver damage, the hepatic progenitor cell response and fibrosis in a mouse model of chronic liver injury. J Hepatol 2007, 47(6):826-833.

87. Boisclair J, Dore M, Beauchamp G, Chouinard L, Girard C: Characterization of the inflammatory infiltrate in canine chronic hepatitis. Vet Pathol 2001, 38(6):628-635

88. Ijzer J, Roskams T, Molenbeek RF, Ultee T, Penning LC, Rothuizen J, van den Ingh TS: Morphological characterisation of portal myofibroblasts and hepatic stellate cells in the normal dog liver. Comp Hepatol 2006, 5:7.

89. Mekonnen GA, ljzer J, Nederbragt H: Tenascin-C in chronic canine hepatitis: immunohistochemical localization and correlation with necro-inflammatory activity, fibrotic stage, and expression of alphasmooth muscle actin, cytokeratin 7, and CD3+ cells. Vet Pathol 2007 44(6):803-813.

90. Bernal W, Auzinger G, Dhawan A, Wendon J: Acute liver failure. Lancet 2010, 376(9736):190-201

91. Larsen FS, Bjerring PN: Acute liver failure. Curr Opin Crit Care 2011, 17(2):160-164

92. Kuntz E, Kuntz HD: Chronic hepatitis. In Hepatology Textbook and Atlas. 3rd edition. Edited by Kuntz E, Kuntz HD. Heidelberg, Germany: Springer; 2008:712-736

93. Poldervaart JH, Favier RP, Penning LC, Van Den Ingh TSGAM, Rothuizen J: Primary hepatitis in dogs: A retrospective review (2002-2006). J Vet Intern Med 2009, 23(1):72-80.

94. Gagne JM, Armstrong PJ, Weiss DJ, Lund EM, Feeney DA, King VL: Clinical features of inflammatory liver disease in cats: 41 cases (1983-1993). J Am Vet Med Assoc 1999, 214(4):513-516.

95. Cohen JC, Horton JD, Hobbs HH: Human fatty liver disease: old questions and new insights. Science 2011, 332(6037):1519-1523.

96. Roskams T, Yang SQ, Koteish A, Durnez A, DeVos R, Huang X, Achten R, Verslype C, Diehl AM: Oxidative stress and oval cell accumulation in mice and humans with alcoholic and nonalcoholic fatty liver disease. Am J Pathol 2003, 163(4):1301-1311.

97. Nobili V, Carpino G, Alisi A, Franchitto A, Alpini G, De Vito R, Onori P, Alvaro D, Gaudio E: Hepatic progenitor cells activation, fibrosis, and adipokines production in pediatric nonalcoholic fatty liver disease. Hepatology 2012, 56(6):2142-2153.

98. Armstrong PJ, Blanchard G: Hepatic lipidosis in cats. Vet Clin North Am Small Anim Pract 2009, 39(3):599-616.

99. Cullen JM, Van den Ingh TSGAM, Van Winkle T, Charles JA, Desmet VJ, Rothuizen J: Morphological classification of parenchymal disorders of the canine and feline liver: 1. Normal histology, reversible hepatocytic injury and hepatic amyloidosis. In WSAVA Standards for clinical and histological diagnosis of canine and feline liver disease. Edited by Rothuizen J, Bunch SE, Charles JA. Edinburgh, Great Britain: Saunders-Elsevier; 2006:77-83. 
100. Kuramitsu K, Sverdlov DY, Liu SB, Csizmadia E, Burkly L, Schuppan D, Hanto DW, Otterbein LE, Popov $Y$ : Failure of fibrotic liver regeneration in mice is linked to a severe fibrogenic response driven by hepatic progenitor cell activation. Am J Pathol 2013, 183(1):182-194.

101. Libbrecht L, Cassiman D, Desmet V, Roskams T: Expression of neural cell adhesion molecule in human liver development and in congenital and acquired liver diseases. Histochem Cell Biol 2001, 116(3):233-239.

102. Van Den Ingh TSGAM, Cullen JM, Twedt DC, Van Winkle T, Desmet VJ, Rothuizen J: Morphological classification of biliary disorders of the canine and feline liver. In WSAVA Standards for clinical and histological diagnosis of canine and feline liver disease. Edited by Rothuizen J, Bunch SE, Charles JA. Edinburgh, Great Britain: Saunders-Elsevier; 2006:61-76.

103. Weiss DJ, Gagne JM, Armstrong PJ: Characterization of portal lymphocytic infiltrates in feline liver. Vet Clin Pathol 1995, 24(3):91-95.

104. Callahan Clark JE, Haddad JL, Brown DC, Morgan MJ, Van Winkle TJ, Rondeau MP: Feline cholangitis: a necropsy study of 44 cats (1986-2008). J Feline Med Surg 2011, 13(8):570-576.

105. Nguyen LV, Vanner R, Dirks P, Eaves CJ: Cancer stem cells: an evolving concept. Nat Rev Cancer 2012, 12(2):133-143.

106. Lee JS, Heo J, Libbrecht L, Chu IS, Kaposi-Novak P, Calvisi DF, Mikaelyan A, Roberts LR, Demetris AJ, Sun Z, Nevens F, Roskams T, Thorgeirsson SS: A novel prognostic subtype of human hepatocellular carcinoma derived from hepatic progenitor cells. Nat Med 2006, 12(4):410-416.

107. Komuta M, Spee B, Vander Borght S, De Vos R, Verslype C, Aerts R, Yano H, Suzuki T, Matsuda M, Fujii H, Desmet VJ, Kojiro M, Roskams T: Clinicopathological study on cholangiolocellular carcinoma suggesting hepatic progenitor cell origin. Hepatology 2008, 47(5):1544-1556.

108. Mishra L, Banker T, Murray J, Byers S, Thenappan A, He AR, Shetty K, Johnson L, Reddy EP: Liver stem cells and hepatocellular carcinoma. Hepatology 2009, 49(1):318-329.

109. Kim H, Choi GH, Na DC, Ahn EY, Kim Gl, Lee JE, Cho JY, Yoo JE, Choi JS, Park YN: Human hepatocellular carcinomas with "Stemness"-related marker expression: keratin 19 expression and a poor prognosis. Hepatology 2011, 54(5):1707-1717

110. Sell S, Leffert HL: Liver cancer stem cells. J Clin Oncol 2008, 26(17):2800-2805.

111. Uenishi T, Kubo S, Yamamoto T, Shuto T, Ogawa M, Tanaka H, Tanaka S, Kaneda K, Hirohashi K: Cytokeratin 19 expression in hepatocellular carcinoma predicts early postoperative recurrence. Cancer Sci 2003, 94(10):851-857.

112. Patnaik AK: A morphologic and immunocytochemical study of hepatic neoplasms in cats. Vet Pathol 1992, 29(5):405-415

113. United Network for Organ Sharing website. [http://www.unos.org/index.php]

114. Strombeck DR, Miller LM, Harrold D: Effects of corticosteroid treatment on survival time in dogs with chronic hepatitis: 151 cases (1977-1985). J Am Vet Med Assoc 1988, 193(9):1109-1113.

115. Rothuizen J: General principles in the treatment of liver disease. In Textbook of Veterinary Internal Medicine. 6th edition. Edited by Ettinger SJ, Feldman E. St. Louis, USA: Elsevier; 2005:1435-1442.

116. Favier RP: Idiopathic hepatitis and cirrhosis in dogs. Vet Clin North Am Small Anim Pract 2009, 39(3):481-488

117. Favier RP, Poldervaart JH, Van Den Ingh TS, Penning LC, Rothuizen J: A retrospective study of oral prednisolone treatment in canine chronic hepatitis. Vet Q 2013, 33(3):113-120.

118. Fox IJ, Chowdhury JR, Kaufman SS, Goertzen TC, Chowdhury NR, Warkentin PI, Dorko K, Sauter BV, Strom SC: Treatment of the Crigler-Najjar syndrome type I with hepatocyte transplantation. N Engl J Med 1998, 338(20):1422-1426.

119. Stephenne $X$, Najimi M, Sibille C, Nassogne MC, Smets F, Sokal EM: Sustained engraftment and tissue enzyme activity after liver cell transplantation for argininosuccinate lyase deficiency. Gastroenterology 2006, 130(4):1317-1323.

120. Puppi J, Tan N, Mitry RR, Hughes RD, Lehec S, Mieli-Vergani G, Karani J Champion MP, Heaton N, Mohamed R, Dhawan A: Hepatocyte transplantation followed by auxiliary liver transplantation-a novel treatment for ornithine transcarbamylase deficiency. Am J Transplant 2008, 8(2):452-457.

121. Soltys KA, Soto-Gutierrez A, Nagaya M, Baskin KM, Deutsch M, Ito $R$, Shneider BL, Squires R, Vockley J, Guha C, Roy-Chowdhury J, Strom SC, Platt JL, Fox IJ: Barriers to the successful treatment of liver disease by hepatocyte transplantation. J Hepatol 2010, 53(4):769-774.
122. Azuma H, Paulk N, Ranade A, Dorrell C, Al-Dhalimy M, Ellis E, Strom S, Kay MA, Finegold M, Grompe M: Robust expansion of human hepatocytes in Fah-/-/Rag2-/-/II2rg-/- mice. Nat Biotechnol 2007, 25(8):903-910.

123. Hickey RD, Lillegard JB, Fisher JE, McKenzie TJ, Hofherr SE, Finegold MJ, Nyberg SL, Grompe M: Efficient production of Fah-null heterozygote pigs by chimeric adeno-associated virus-mediated gene knockout and somatic cell nuclear transfer. Hepatology 2011, 54(4):1351-1359.

124. Grompe M, Strom S: Mice with human livers. Gastroenterology 2013 145(6):1209-1214.

125. Forbes SJ, Newsome PN: New horizons for stem cell therapy in liver disease. J Hepatol 2012, 56(2):496-499.

126. Arends B, Spee B, Schotanus BA, Roskams T, van den Ingh TS, Penning LC, Rothuizen J: In vitro differentiation of liver progenitor cells derived from healthy dog livers. Stem Cells Dev 2009, 18(2):351-358.

127. Huch M, Boj SF, Clevers H: Lgr5(+) liver stem cells, hepatic organoids and regenerative medicine. Regen Med 2013, 8(4):385-387.

128. Liras A: Future research and therapeutic applications of human stem cells: general, regulatory, and bioethical aspects. J Trans/ Med 2010, 8:131-5876. 8-131.

129. Watson PJ, Roulois AJ, Scase TJ, Irvine R, Herrtage ME: Prevalence of hepatic lesions at post-mortem examination in dogs and association with pancreatitis. J Small Anim Pract 2010, 51(11):566-572.

130. Jorns C, Ellis EC, Nowak G, Fischler B, Nemeth A, Strom SC, Ericzon BG: Hepatocyte transplantation for inherited metabolic diseases of the liver. J Intern Med 2012, 272(3):201-223

131. Dunn TB, Kumins NH, Raofi V, Holman DM, Mihalov M, Blanchard J, Law WR, Rastellini C, Benedetti E: Multiple intrasplenic hepatocyte transplantations in the dalmatian dog. Surgery 2000, 127(2):193-199.

132. Benedetti E, Kirby JP, Asolati M, Blanchard J, Ward MG, Williams R, Hewett TA, Fontaine M, Pollak R: Intrasplenic hepatocyte allotransplantation in dalmation dogs with and without cyclosporine immunosuppression. Transplantation 1997, 63(9):1206-1209.

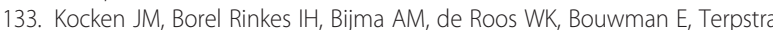
OT, Sinaasappel M: Correction of an inborn error of metabolism by intraportal hepatocyte transplantation in a dog model. Transplantation 1996, 62(3):358-364.

134. Favier RP, Spee B, Penning LC, Rothuizen J: Copper-induced hepatitis: the COMMD1 deficient dog as a translational animal model for human chronic hepatitis. Vet Q 2011, 31(1):49-60.

135. Favier RP, Spee B, Schotanus BA, van den Ingh TS, Fieten $H$, Brinkhof $B$, Viebahn CS, Penning LC, Rothuizen J: COMMD1-deficient dogs accumulate copper in hepatocytes and provide a good model for chronic hepatitis and fibrosis. PLoS One 2012, 7(8):e42158.

136. Thomas JA, Pope C, Wojtacha D, Robson AJ, Gordon-Walker TT, Hartland S, Ramachandran P, Van Deemter M, Hume DA, Iredale JP, Forbes SJ: Macrophage therapy for murine liver fibrosis recruits host effector cells improving fibrosis, regeneration, and function. Hepatology 2011 53(6):2003-2015.

137. Fouraschen SM, Pan Q, de Ruiter PE, Farid WR, Kazemier G, Kwekkeboom J, ljzermans JN, Metselaar HJ, Tilanus HW, de Jonge J, van der Laan LJ: Secreted factors of human liver-derived mesenchymal stem cells promote liver regeneration early after partial hepatectomy. Stem Cells Dev 2012, 21(13):2410-2419.

doi:10.1186/1746-6148-10-137

Cite this article as: Kruitwagen et al:: Hepatic progenitor cells in canine and feline medicine: potential for regenerative strategies. BMC Veterinary Research 2014 10:137. 